\title{
SYARI'AH DAN TASAWUF: \\ Pergulatan Integratif Kebenaran dalam Mencapai Tuhan
}

\author{
Syamsul Rijal ${ }^{1}$ dan Umiarso ${ }^{2}$ \\ ${ }^{1}$ Universitas Islam Negeri ar-Raniry Banda Aceh, Indonesia \\ ${ }^{2}$ Universitas Muhammadiyah Malang, Indonesia \\ umiarso@umm.ac.id
}

\begin{abstract}
Islamic law (shari'a) and tasawwuf are two entities that are still stuck as stand-alone variants, even these two entities are often confronted vis a vis. The shari'ah that stands consistently on the exoteric dimension (claims) outwardly claims that the Sufis as a whole ignore the outward stipulations of religious law and substitute the fundamental practice with their own design innovations, thus removing themselves from the true Muslim community. While the Sufi selfconfused in the esoteric world states that the fuqaha only see the explicit side that is on the pages of the Qur'an and only be a mere formality without capturing the essence or substance of Islamic teachings. Shari'ah, tarekat, essence, and makrifat are integrative steps in Sufism. Therefore, the two dimensions are a unified one (integrative-monochotomic) between one dimension and another. Between these two dimensions is also open space to find the "ultimate truth" to one God.
\end{abstract}

Keywords: Shari'ah, Tasawwuf, and The Truth Reaches God.

\begin{abstract}
Abstrak
Hukum Islam (syari'ah) dan tasawuf adalah dua entitas yang sampai saat ini masih terpancang sebagai varian yang berdiri sendiri, bahkan dua entitas ini sering dihadapkan secara vis a vis. Syari'ah yang berdiri secara konsisten pada dimensi eksoteris (lahiriah) mengklaim bahwa sufi secara keseluruhan mengabaikan ketentuan lahiriah hukum agama dan menggantikan praktik mendasar dengan inovasi desain mereka sendiri, sehingga menghapus diri dari komunitas muslim sejati. Sedangkan para sufi sendiri yang berkecipung di dunia esoteris menyatakan bahwa para fuqaha hanya melihat sisi eksplisit yang ada pada lembar-lembar al-Qur'an dan hanya bersikap formalitas belaka tanpa menangkap esensi atau substansi ajaran Islam. Syari'at, tarekat, hakekat, dan makrifat adalah langkah integratif dalam sufisme. Oleh karena itu, dua dimensi tersebut merupakan satu kesatuan yang tidak saling menegasikan (integratif-monokhotomik) antara satu dimensi dengan dimensi lainnya. Antara dua dimensi ini terbuka ruang untuk menemukan "kebenaran hakiki" menuju satu Tuhan.
\end{abstract}

Kata Kunci: Syari'ah, Tasawuf, dan Kebenaran Mencapai Tuhan. 


\section{Pendahuluan}

Hukum Islam - baca pada konteks ini sebagai syari'ah Islam - yang diproklamirkan sebagai "sumber prinsip undang-undang" dan sebagai jantung Islam ${ }^{2}$ merupakan suatu entitas yang sering dihadapkan secara vis a vis dengan tasawuf. Konsekuensinya antara syari'ah dan tasawuf (sufisme) menjadi dua entitas yang oleh beberapa pakar dinilai tidak bisa disatukan, bahkan dinilai merupakan dua entitas yang bertolak belakang secara praksis ataupun secara substansial. ${ }^{3}$ Memang ketika dilihat pada sisi penekanannya, sejak abad pertama Islam, (pemikiran) hukum Islam telah bergulat dengan masalah sejauhmana akal manusia dapat membimbing manusia dalam melakukan materi dan urusan spiritual. ${ }^{4}$ Sedangkan tasawuf merupakan entitas yang memusatkan perhatian pada pembersihan aspek rohani manusia yang selanjutnya dapat menimbulkan akhlak mulia; ${ }^{5}$ walaupun pada perkembangan awalnya lebih dilekatkan pada stigma gerakan oposisi. ${ }^{6}$

Dengan demikian, posisional karakteristik dari dua entitas tersebut seakan-akan bertolak belakang; syariah lebih memusatkan pada dimensi eksoteris dan tasawuf pada dimensi esoteris. Seakan menjadi suatu kelaziman dalam Islam, polarisasi antara eksoterisme dan esoterisme sangat terasa. Dalam al-Qur'an, Allah menyajikan diri-Nya sebagai, pada saat yang sama, The Outer (al-Zahir) dan The Inner (al-

\footnotetext{
${ }^{1}$ Juan E. Campo, Encyclopedia of Islam (New York: Facts On Fire, Inc., 2009), 211.

${ }^{2}$ M. B. Hooker \& Virginia Hooker, "Sharia", dalam Greg Fealy \& Virginia Hooker (Editor), Voices of Islam In Southeast Asia: A Contemporary Sourcebook (Singapore: ISEAS, 2006), 137.

${ }^{3}$ Abdul Hadi W.M., "Islam di Indonesia dan Transformasi Budaya", dalam Aan Rukmana, dkk., Mengenal Islam Jalan Tengah: Buku Daras Pendidikan Agama Islam untuk Perguruan Tinggi (Jakarta: Dian Rakyat, 2012), 354.

${ }^{4}$ Wael B. Hallaq, An Introduction to Islamic Law (Cambridge: Cambridge University Press, 2009), 14.

${ }^{5}$ Abuddin Nata, Metodologi Studi Islam (Jakarta: Rajawali Press, 2011), 283.

${ }^{6}$ Nurcholish Madjid, Islam Doktrin dan Peradaban: Sebuah Telaah Kritis Tentang Masalah Keimanan, Kemanusiaan, dan Kemodernan (Jakarta: Paramadina, 2000), 254.
}

Batin) (QS. al-Hadid: 3). ${ }^{7}$ Hal ini telah menjadi kesepakatan bahwa tasawuf pada hakikatnya adalah dimensi yang dalam dan esoteris dari Islam (the inner and esoteric dimension of Islam) yang bersumber dari al-Qur'an dan Hadis serta perilaku Nabi Muhammad Saw dan para sahabatnya; sedangkan syari'ah adalah dimensi luar ajaran Islam. ${ }^{8}$ Kesepakatan ini telah menjadi standar dan mengakar kuat dalam diskursus studi Islam sampai saat ini.

Akan tetapi, diferensiasi tersebut melahirkan stigma berupa kritik antara dua varian yang memiliki pusat perhatian yang berbeda (eksoteris dan esoteris) tersebut. Artinya, antara varian Syari'ah dengan Tasawuf saling mengkritik tentang keabsahan masing-masing dimensi. Salah satu kritik terhadap tasawuf selama berabadabad sering memunculkan argumentasi bahwa sufi secara keseluruhan mengabaikan ketentuan lahiriah hukum agama dan menggantikan praktik mendasar dengan inovasi desain mereka sendiri, sehingga menghapus diri dari komunitas muslim sejati. ${ }^{9}$ Hal ini terjadi pada Dzunnun al-Misri yang telah benar-benar dituduh menyelewengkan ajaran Islam yang terjadi pada tahun 240 H/854 M di Baghdad. ${ }^{10}$ Lazim apabila muncul kecurigaan ahli Fiqh terhadap ahli tasawuf, baik yang penganut corak tasawuf teologi ataupun terhadap mereka yang menganut tasawuf falsafi. ${ }^{11}$

Sedangkan para pelaku tasawuf juga mengkritik balik para fuqaha tersebut yang hanya melihat sisi eksplisit yang ada pada lembar-lembar al-Qur'an dan ia hanya bersikap formalitas belaka, tanpa menangkap esensi atau substansi ajaran Islam; walaupun sejak awal

${ }^{7}$ Eric Geoffroy, Introduction to Sufism: The Inner Path of Islam (Indiana: World Wisdom, Inc., 2010), 1.

${ }^{8}$ Asep Usman Ismail, "Tasawuf", dalam Taufik Abdullah, dkk., Ensiklopedi Tematis Dunia Islam: Ajaran, Jilid 3 (Jakarta: PT. Ichtiar Baru Van Hoeve, 2002), 306.

${ }^{9}$ John Renard, The A to $Z$ of Sufism (Toronto: The Scarecrow Press, Inc., 2009), 142.

${ }^{10}$ Fazlur Rahman, Islam, Peterj. Ahsin Mohammad (Bandung: Pustaka, 1984), 194.

${ }^{11}$ Mahyuddin, Kuliah Akhlaq Tasawuf (Jakarta: Kalam Mulia, 2003), 69 . 
ia telah menyadari akan terkesampingkan atau terlewatkannya aspek "batiniyah" daripada agama. ${ }^{12}$ Para fuqaha menyakini bahwa Tuhan, sebagai pencipta, berkeinginan agar manusia hidup dengan cara tertentu, dan juga telah mengungkapkan cara-cara bagi manusia. ${ }^{13}$ Oleh sebab itu, perintah-perintah yang jelas dan spesifik dari al-Qur'an dan Sunnah merupakan inti dari syari'ah dan pemahaman mereka dapat tersampaikan dengan jelas. ${ }^{14}$ Pada kerangka ini sangat jelas bahwa syari'ah merupakan aturan yang diciptakan untuk manusia agar ia berpegang pada aturan tersebut dalam berhubungan dengan Tuhan, sesamanya, dan dengan alam.

Persoalan stigma tersebut akhirnya menciptakan rentetan alur sejarah pahit pada peradaban Islam itu sendiri salah satunya adalah insiden al-fitnah al-kubra yang mengantarkan jatuhnya Khalifah Ali dari ke-khilafah-an, diganti Muawiyah merupakan sumber utama bagi perpecahan kaum muslimin dalam berbagai sekte dan aliran seperti munculnya Khawarij yang menganggap Khalifah Ali telah kafir. Bahkan aliran ini menganggap darah umat Islam yang menantang diri mereka halal ditumpahkan dan kekayaan mereka halal dirampas. ${ }^{15}$ Mereka melegitimasi perbuatannya dengan menggunakan ayat-ayat secara eksoteris dengan tetap pada arus kepentingan mereka. Artinya, pola penafsiran mereka lebih mengarah pada makna lahiriah dari teks al-Qur' an yang diyakini sebagai "kebenaran" hakiki. Namun, latar peristiwa munculnya aliran ini lebih dimotori oleh muatan-muatan politik (kekuasaan) yang akhirnya merembes - atau memang dipolitisir atas nama agama - pada nuansa keagamaan.

\footnotetext{
${ }^{12} \mathrm{M}$. Amin Abdullah, Studi Agama: Normativitas atau Historisitas? (Yogyakarta: Pustaka Pelajar, 2002), 152.

${ }^{13}$ Robert S. Ellwood \& Gregory D. Alles, The Encyclopedia of World Religions: Revised Edition (New York: Facts On File, Inc., 2007), 418.

${ }^{14}$ Mohammad Hashim Kamali, Shari'ah Law: An Introduction (Oxford: A Oneworld Book, 2008), 39.

${ }^{15}$ Stephen Sulaiman Schwartz, Two Faces of Islam: The House of Sa'ud from Tradition to Terror, Peterj. Hodri Ariev (Jakarta: Blantika, 2007), 67.
}

Belakangan juga telah terjadi suatu percikan atau letupan sejarah yang mengatasnamakan kesucian agama, yaitu peristiwa eksekusi Mansur al-Hallaj (w. 309 H) yang didakwa menyebarluaskan ajaran al-hulul dalam tasawuf. Ia menjadi martir besar sufisme karena pengakuan terbuka tentang misteri kesatuan Ilahi dan mengabaikan kepatutan syari'ah. ${ }^{16}$ Oleh sebab itu, ajaran al-hulul ini diputuskan sesat oleh penguasa berdasarkan legitimasi para fuqaha mazhab dhahiriy. Akhirnya, putusan eksekusi ini menyebabkan perubahan radikal dalam sejarah tasawuf, ${ }^{17}$ yaitu terjadinya saling curiga atau ketimpangan relasional antara syari'ah (hukum Islam) dan tasawuf (hakikat); antara dimensi eksoteris dan dimensi esoteris. Akan tetapi jika ditelisik lebih komprehensif, eksekusi tersebut tidak murni karena "bentuk keyakinan" yang dipegang oleh al-Hallaj sendiri, namun lebih didorong oleh muatan politik penguasa yang ingin menghancurkan kelompok-kelompok marginal seperti syi'ah, qaramithah, dan golongan nonmuslim.

Hal-hal tersebut atau ketegangan dalam sejarah pemikiran Islam tersebut secara eksplisit lebih dimotori oleh faktor politis (kekuasaan) yang berkelindan dengan nilai-nilai sakralitas agama. Entitas sakralitas agama ini yang akhirnya menutupi nuansa ketegangan politis tersebut, sehingga ia terbaca sebagai suatu peristiwa yang murni sebagai suatu peristiwa keagamaan an sich. Ketegangan ini sebenarnya telah mulai "didamaikan" oleh beberapa pakar (ulama') sebut saja seperti al-Ghazali (1058-1111 M.) yang mengembangkan suatu tesis bahwa tasawuf yang terpadu secara baik dengan syariah diakui sebagai mu'tabarah (absah), dan yang tidak memenuhi kriteria itu dinyatakan sebagai ghayr mu'tabarah (tidak absah). ${ }^{18}$ Walaupun

\footnotetext{
${ }^{16}$ William C. Chittick, Sufism: A Beginner's Guide (Oxford: A Oneworld Book, 2008), 35.

${ }^{17}$ Eric Geoffroy, 70.

${ }^{18}$ Nurcholish Madjid, Islam Agama Peradaban: Membangun Makna dan Relevansi Doktrin Islam dalam Sejarah (Jakarta: Paramadina, 2000), 77.
} 
sebenarnya para praktisi tasawuf seperti Ibnu 'Arabi tidak pernah memisahkan antara syari'ah dengan tasawuf (hakikat). Artinya, pendekatan kontemplatif dan batini yang digunakan Ibnu 'Arabi bukan merupakan ekspresi parsialistik, melainkan bentuk komprehensivitas aspek dan dimensi ajaran Islam, baik aspek literal maupun kiasan, teoretikal, dan praktikal, atau dimensi eksoteris dan esoteris. ${ }^{19}$ Dengan demikian, entitas tersebut (syari'ah dan tasawuf) merupakan dua entitas yang bisa dilihat secara integral tanpa ada upaya menegasikan satu entitas dalam bingkai pencarian "kebenaran” menuju Tuhan.

\section{Syari'ah: Sisi Eksoteris dalam Islam}

Hukum menurut para ahli hukum Islam adalah tata aturan yang mencakup seluruh perilaku manusia, baik dalam hubungan antar manusia ataupun hubungan manusia dengan Tuhan. Artinya, bahwa hukum Islam merupakan suatu disiplin hermeneutis yang menggali dan menafsirkan wahyu melalui tradisi. ${ }^{20}$ Batasan ini memiliki kemiripan dengan batasan teknis dari syari'ah sebagai sistem norma hukum Ilahi yang mengatur hubungan manusia dengan Tuhan, hubungan manusia sesama manusia, hubungan manusia dengan benda di dalam lingkungan hidupnya. ${ }^{21}$ Dari batasan ini terdapat sisi tumpang tindih antara hukum Islam dan syari'ah yang tentunya tidak mampu memberikan batasan pasti antara keduanya. Lazim apabila dalam pemakaiannya sering digunakan dua istilah untuk hukum Islam, yaitu syari'ah dan Fiqh. Penggunaan istilah ini akhirnya memunculkan kerancuan pengertian Fiqh dengan syari'ah, sehingga pada kerangka ini ada sebagian kalangan yang mempunyai pendirian bahwa hukum Islam (Fiqh)

\footnotetext{
${ }^{19}$ Nurasiah Faqihsutan Hrp., Meraih Hakikat Melalui Syariat: Telaah Pemikiran Syekh al-Akbar Ibn 'Arab (Bandung: Mizan, 2005), 24.

${ }^{20}$ Ashk P. Dahlen, Islamic Law, Epistemology and Modernity: Legal Philosophy in Contemporary Iran (New York: Routledge, 2003), 14.

${ }^{21}$ Muniron, dkk., Studi Islam di Perguruan Tinggi (Jember: STAIN Jember Press, 2010), 45.
}

merupakan atau sekelompok dengan syari'ah.

Namun, ada juga yang menyatakan bahwa suatu sistem peraturan yang menggariskan secara sistematis amal shaleh atau perilaku manusia (umat muslim) disebut syari'ah. Dengan demikian sangat jelas, pada mulanya istilah syari'ah mengacu pada doktrin Islam secara totalitas dan komprehensif, termasuk bidang aqidah dan akhlaq. Artinya, syari'ah mencakup beberapa dimensi yang meliputi ranah hukum, akhlaq, dan aqidah dalam Islam - bisa dikatakan menyangkut aspek eksoteris dan esoteris sekaligus. Akan tetapi, perkembangan selanjutnya, istilah itu mengalami penyempitan makna sebatas doktrin agama yang menyangkut hal-hal lahiriah (eksoteris), sehingga pengertian syari'ah menjadi identik dengan Fiqh (yurisprudensi Islam). ${ }^{22}$ Analisis ini memberikan suatu pemahaman tentang integralisasi ajaran Islam yang selama ini terkesan saling menegasikan terutama antara syari' ah dan tasawuf. Peristiwa ini seakan mengungkap ada "gerakan epistemologis" yang mereduksi kegeneralan syari'ah sebagai suatu sistem komprehensif (eksoteris dan esoteris) dalam anatomi ajaran Islam, sehingga penyempitan makna syari'ah menjadi peristiwa yang menyebabkan dikhotomi dimensi dalam ajaran Islam. Hal ini bisa dikatakan sebagai "ijtihad epistemologis" dalam sejarah pemikiran Islam yang sampai saat ini masih terasa getarannya.

Terlepas dari hal tersebut, secara faktual terma Fiqh sebagai suatu anatomi dalam Islam dapat dibedakan berdasarkan pada sisi generiknya, yaitu: pertama, istilah Fiqh berarti paham (understanding) yang menjadi suplemen terhadap istilah ilmu (menerima pelajaran) terhadap nash normatif, yakni al-Qur'an, Sunnah atau Hadis; kedua, Fiqh dan ilmu keduanya mengacu pada satu entitas yaitu pengetahuan (knowledge), sehingga kedua terma tersebut menjadi identik

\footnotetext{
${ }^{22}$ Lebih detailnya lihat Budhy Munawar-Rachman (Editor), Kontekstualisasi Doktrin Islam dalam Sejarah, (Jakarta: Paramadina, 1994), 124; lihat juga Ahmad Sukardja, "Pendahuluan", dalam Taufiq Abdullah, dkk., Ensiklopedi Tematis Dunia (Jilid 3), 2-3.
} 
untuk dipertautkan; dan ketiga, Fiqh berarti suatu jenis disiplin dari jenis-jenis pengetahuan Islam atau ilmu-ilmu keislaman. ${ }^{23}$ Sedangkan syari'ah - secara etimologis - dapat dimaknai sebagai jalan yang lurus (al-Thariqah al-Mustaqimah); sumber atau aliran air yang digunakan untuk minum; atau juga tangga atau tempat naik yang bertingkat-tingkat. ${ }^{24}$ Dari sisi ini bisa dikatakan bahwa syari'ah sebagai al-thariqah almustaqimah merupakan kebutuhan pokok yang akan menyelamatkan dan membawa kebaikan bagi umat manusia; sebab dalam konteks ini, agama memberikan petunjuk, jalan, dan ramburambu yang bisa mengantarkan manusia pada kebahagiaan yang hakiki. Syariah pada tataran ini merupakan segala ketentuan Allah - yang terkodifikasi dalam al-Qur'an dan al-Hadis - bagi hambanya yang meliputi akidah, ibadah, akhlak, dan tata kehidupan manusia untuk mencapai kebahagiaan manusia di dunia dan akhirat.

Dari kerangka tersebut sangat jelas bahwa syari'ah merupakan jalan untuk tempat penyiraman, jalan yang jelas yang harus diikuti dan jalan yang harus ditempuh oleh orang yang beriman untuk mendapatkan bimbingan dalam dunia ini dan pembebasan di akhirat. ${ }^{25}$ Dengan demikian, syari'ah mengacu pada perintah, larangan, bimbingan, dan prinsip-prinsip yang telah ditujukan oleh Allah kepada umat manusia berkaitan dengan perilaku mereka di dunia ini dan keselamatan di akhirat. ${ }^{26}$ Semua hal tersebut terkodifikasi dalam al-Qur'an dan al-Hadis. Alur pemikiran ini sangat jelas bahwa syariah merupakan hukum-hukum yang diadakan oleh Allah yang dibawa oleh Nabi-Nya, termasuk Nabi Muhammad Saw, baik hukum yang berkaitan dengan cara berbuat yang disebut dengan far'iyah atau amaliyah yang untuknya dihimpun ilmu

${ }^{23}$ A. Qodri Azizy, Membangun Fondasi Ekonomi Umat: Meneropong Prospek Berkembangnya Ekonomi Islam (Yogyakarta: Pustaka Pelajar, 2004), 181-183.

${ }^{24}$ Muhaimin, dkk., Studi Islam: Dalam Ragam Dimensi \& Pendekatan (Jakarta: Prenada Media, 2012), 277.

${ }^{25}$ Mohammad Hashim Kamali, 14.

${ }^{26}$ Ibid., 14.
Fiqh, maupun yang berkaitan dengan kepercayaan yang disebut dengan ashliyyah atau i'tiqdiyyah yang untuknya dihimpun ilmu kalam. ${ }^{27}$

Dari pola diferensiasi yang berdasarkan sisi generik tersebut sangat jelas perbedaan antara Fiqh dengan syari'ah terutama dari segi keluasan cakupannya. Terma syari'ah mengacu pada suatu bentuk kumpulan perintah dan larangan yang disampaikan Allah melalui Rasul-Nya, termasuk Nabi Muhammad Saw (hukum in abstracto) juga mencakup sistem kepercayaan yang bersifat "i'tiqadi". Sedangkan terma Fiqh adalah kumpulan hukum yang bersifat 'amali yang dipetik dari dalil-dalil yang bersumber dari al-Qur'an dan al-Hadis dengan alur yang terinci dan jelas (hukum in concreto). Dalam memunculkan hukum-hukum yang bersifat 'amali ini perlu adanya suatu usaha, yaitu ijtihad yang dilakukan dengan metode-metode yang sudah baku seperti qiyas (silogisme), bayan, nasikh mansukh, preferensi juristic (istihsan), anggapan berlakunya kontinuitas (istishhab), dan kaidah interpretasi serta deduksi. ${ }^{28}$ Jadi, Fiqh ialah kumpulan hukum yang diperoleh dari teks normatif (al-Qur'an dan al-Hadis) melalui kaidah-kaidah yang umum digunakan serta telah menjadi standar dan kebanyakan digunakan untuk memunculkan hukum Islam yang bersifat operasional.

Ketika ruang lingkup operasionalisasi sudah terpetakan, antara syari'ah dan Fiqh memiliki minat yang mencakup dalam segala tindakan manusia. Syari'ah dan Fiqh mengatur manusia ke dalam berbagai kategori, mulai dari aspek moral sampai pada tatanan kehidupan lainnya seperti tata perilaku sehari-hari (makan, berpakaian, dan lain sebagainya). Dengan demikian, semua tindakan yang dianggap sebagai syar'i (yaitu, tunduk pada peraturan syari'ah dan karena

\footnotetext{
${ }^{27}$ Muhaimin, dkk., 277.

${ }^{28}$ Pada konteks metode-metode sistematis ini lebih detailnya lihat Ahmad Hassan, The Principles of Islamic Jurisprudence: The Command of The Syari'ah and Juridical Norm (New Delhi: Adam Publisher \& Distributor, 1994), 13-14.
} 
itu diucapkan sebagai hukum-hukum menjadi sebuah perintah moral yang bersifat legalistik), ${ }^{29}$ dan dikategorikan sesuai dengan lima norma atau hukum, yaitu: pertama, kategori wajib, yaitu perintah yang harus atau mesti dikerjakan. Jika perintah dipatuhi (dikerjakan), maka yang mengerjakannya mendapat pahala; jika tidak dikerjakan, maka ia berdosa; kedua, kategori sunnat (anjuran). Pada kategori ini jika sesuatu tersebut dikerjakan dapat pahala, jika tidak dikerjakan tidak berdosa; ketiga, kategori haram, yaitu larangan keras yang jika dikerjakan berdosa dan jika tidak dilanggar tidak berdosa, apabila ditinggalkan akan mendapat pahala; keempat, kategori makruh, yaitu larang yang tidak keras. Kalau dilanggar tidak dihukum, dan jika ditinggalkan diberi pahala; dan kelima, kategori mubah, yaitu sesuatu yang boleh dikerjakan dan boleh ditinggalkan. Kalau dikerjakan, tidak berpahala dan tidak pula berdosa. ${ }^{30}$

Antara syari'ah dan Fiqh pada aspek ini lebih dimaknai sebagai hukum Islam (yurisprudensi Islam) yang memiliki tujuan untuk mengejawantahkan segala bentuk perintah dan larangan Tuhan yang terkodifikasi dalam al-Qur'an dan al-Hadis. Nash-nash lahiriah yang tersurat dalam nash normatif tersebut yang menjadi sentral dalam pemunculan tata aturan untuk manusia. Para fuqaha secara konsisten mencoba untuk mengembalikan berbagai aspek dan dimensi pada makna lahiriah nash atau ajaran Islam tersebut. Fakta lain yang tidak bisa dielakkan adalah sisi tujuan transendental, yaitu untuk mendapatkan ridha Ilahi yang mengantarkan manusia pada kebenaran yang hakiki (Tuhan), sehingga pada konteks ini seseorang dapat dikatakan seorang muslim yaitu suatu predikat untuk "orang yang tunduk kepada Allah semata". ${ }^{31}$

\footnotetext{
${ }^{29}$ Wael B. Hallaq, 20.

${ }^{30}$ Untuk hal ini lebih detailnya lihat Sulaiman Rasjid, Fiqh Islam: Hukum Fiqh Lengkap (Bandung: Sinar Baru Algensindo, 2002), 1. ${ }^{31}$ Masoud Kheirabadi, Religions of the World: Islam (Philadelphia: Chelsea House Publishers, 2004), 3.
}

\section{Tasawuf: Sisi Esoteris Dalam Islam}

Trilogi ajaran Islam yang memuat varian aqidah (Iman), syari'ah (Islam), dan akhlaq (Ihsan) secara universal dipandang sebagai pokok ajaran Islam. Aqidah yang berarti simpulan, ikatan, sangkutan, perjanjian, dan kokoh; yang secara teknis diartikan sebagai sistem iman, kepercayaan, dan keyakinan. ${ }^{32}$ Oleh sebab itu, wajar apabila sering dikatakan aqidah mengajarkan sistem keimanan dan keyakinan yang akan dijadikan sebagai landasan pandangan hidup, sehingga bentuk-bentuk ajaran yang ada dalam Islam tentang ketuhanan dan kepercayaan disebut sebagai aqidah. ${ }^{33}$ Sedangkan syari'ah (hukum Islam) mengajarkan pola hidup beraturan dengan suatu tatanan hukum komprehensif, seperti yang telah dijelaskan pada sub sebelumnya, dan akhlaq yang berarti budi pekerti, etika, dan moral menyadarkan muslim atas segala tindakan yang dilakukannya berdasarkan pada tata aturan dan etika Islam. Akhlaq mempunyai kaitan nilainilai luhur Islam, sehingga doktrin nilai etis Islam hanya untuk penyempurnaan martabat manusia dan juga sebagai pengharmonisan tatanan masyarakat. Di samping sebagai aturan legal formal yang terkandung dalam syari'ah dan aqidah, akhlaq juga membingkai doktrinnya dengan aturan-aturan yang bersifat legal formal yang mengarahkan tindakan manusia bersifat etik. Dengan demikian, Islam mengajarkan etika paripurna yang memiliki sifat antisipatif jauh ke depan dengan dua ciri utama, yaitu: pertama, akhlaq Islam - sebagai jati diri ajaran Islam itu sendiri - tidak menentang fitrah manusia; dan kedua; akhlaq Islam yang bersifat rasional. ${ }^{34}$

Berdasarkan pada pijakan dasar tersebut, Islam muncul dengan membawa panji-panji keluhuran akhlaq pemeluknya. Ketika dilihat dari sisi sejarah, dengan ajaran tersebut - baca Islam-Nabi Muhammad Saw mampu melahirkan

\footnotetext{
${ }^{32}$ Muhaimin, dkk., 259.

${ }^{33}$ Abdul Aziz Dahlan, "Akidah", dalam Taufiq Abdullah, dkk., Ensiklopedi Tematis Dunia (Jilid 3), 9.

${ }^{34} \mathrm{Ahmad}$ Sukardja, 5.
} 
masyarakat yang ideal pada masanya, terdiri dari orang-orang yang tidak mementingkan diri sendiri yang selama \pm 10 tahun, sejak Hijrah dari Mekkah ke Yastrib (Madinah) pada tanggal 12 Rabiul Awal 1 H. (28 Juni 622 M.) berhasil bereksperimen dalam melaksanakan demokrasi sejati di dunia berdasarkan persamaan, keadilan, dan moralitas. ${ }^{35}$ Namun, ketiga dimensi yang membentuk ajaran pokok dalam Islam tersebut masih belum menyentuh tataran spiritual yang lebih dalam pada diri manusia. Artinya, ketiga dimensi tersebut pada operasionalisasinya lebih menitikberatkan pada pendekatan rasional (nalar) terhadap nash normatif, yaitu al-Qur'an dan al-Hadis. Ketiga dimensi ini memunculkan kesan bahwa pendekatan yang dipunyai hanya dapat memenuhi kepuasan rasio daripada kepuasan rohani; hanya mengungkap aspek eksoteris daripada aspek esoteris ajaran Islam (alQur'an dan al-Hadis). Untuk mengisi kerangka yang "kosong" ini muncul suatu pendekatan rohaniah atas kandungan al-Qur'an dan al-Hadis untuk mengungkap makna esoteris dari ajaran Islam tersebut serta sebagai upaya menggapai "kebenaran hakiki”, yaitu Tuhan. Pendekatan ini pada gilirannya melahirkan tatanan ajaran spiritual dalam Islam yang dikenal dengan tasawuf. Di mana tasawuf yang disampaikan oleh Islam, memberikan kontribusi melalui berbagai aspek terhadap perspektif yang luas yang telah dibuka oleh konsep-konsep Islam tentang nabi dan nubuat. $^{36}$

Kata tasawuf pada kerangka studi pemikiran Islam masih menjadi suatu entitas yang diperdebatkan. Ada kalangan yang menyatakan kata tasawuf masuk dalam "babut-tafaul" dengan wazan tasawwufa, yatasawwuf, tasawwufan; yang bisa dijadikan suatu tatanan kata seperti tasawwuf al-rajul, yakni seorang laki-laki telah berpindah

${ }^{35}$ Karen Amstrong, A History of God: The 4,000-Year Quest of Judaism, Christianity, and Islam, Peterj. Zainul Am (Bandung: Mizan, 2002), 502-503.

${ }^{36}$ Eric Geoffroy, 33. dari kehidupan biasa pada kehidupan sufi. ${ }^{37}$ Pada sisi yang lain ada pula yang mengatakan bahwa kata "tasawuf" berasal dari kata "safa" yang artinya suci, bersih atau murni; atau dari kata "saf" yang artinya saf atau baris; dari kata "suffah" yang berarti serambi masjid; dan juga "shuf" yaitu bulu domba; ${ }^{38}$ shuf ini merupakan pakaian bersahaja yang terbuat dari wol kasar yang diduga merupakan pakaian kegemaran Nabi Muhammmad. ${ }^{39}$

Dari beberapa penjelasan yang paling diterima secara luas - asal kata tasawuf yang berkelindan dalam khazanah pemikiran Islam - adalah derivasi etimologis istilah dari bahasa Arab untuk "wol" (shuf) yang menghubungkan praktisi dengan preferensi miskin, pakaian kasar. Penjelasan ini jelas mengidentifikasi tasawuf dengan praktik asketis dan pentingnya mewujudkan kemiskinan spiritual melalui kemiskinan materi. Bahkan, beberapa deskripsi awal di Barat sekarang banyak dikaitkan dengan fenomena yang lebih besar dari tasawuf yang mengidentifikasi mereka dengan istilah Arab Faqir (pengemis) atau yang setara dengan Persia yang paling umum, yaitu Darwish. ${ }^{40}$ Jadi, sufi adalah orang yang memakai wol kasar untuk menjauhkan diri dari dunia materi dan memusatkan perhatian pada alam rohani. Orang yang pertama memakai kata sufi kelihatannya Abu Hasyim al-Kufi di Irak (w. 150 H.). ${ }^{41}$ Akan tetapi, ada pula pandangan yang tidak sejalan salah satunya yang menyatakan bahwa "Tak ada bukti bahwa nama ini merupakan kata jadian atau kata kias dari bahasa. Yang jelas nama itu adalah sebuah gelas. Pendapat bahwa sufi asal katanya dari shafa atau dari kata shuffah, tidaklah benar

\footnotetext{
${ }^{37}$ Mustafa Zahri, Kunci Memahami Ilmu Tasawuf (Surabaya: Bina Ilmu, 1995), 45.

${ }^{38}$ Asmaran AS., Pengantar Studi Tasawuf (Jakarta: Rajawali Press, 1996), 42.

${ }^{39}$ Karen Amstrong, 300.

${ }^{40}$ John Renard, 5.

${ }^{41}$ Budhy Munawar-Rachman (Editor), 42; lihat juga $\mathrm{H}$. Wilberforce-Clarke, "Pendahuluan", dalam Syihabuddin 'Umar Suhrawardi, 'Awarif al-Ma'arif: Puncak Pengetahuan Ahli Makrifat, Peterj. Ilma Nugrahani Ismail (Bandung: Pustaka Hidayah, 2007), 13; dalam Mahyuddin, Kuliah Akhlaq Tasawuf (Jakarta: Kalam Mulia, 2003), 49-51.
} 
dari segi filologi. Demikian pula mereka yang mengatakan asal kata sufi dari shuf, sebab orang sufi tidak mengkhususkan diri untuk memakai pakaian dari bulu domba. ${ }^{42}$

Sedangkan ketika ditelisik dari sudut pandang terminologis, tasawuf didefinisikan sebagai ajaran untuk mengenal dan mendekatkan diri kepada Allah sehingga memperoleh hubungan langsung secara sadar dengan-Nya; ${ }^{43}$ yang bersifat kerohanian atau kebatinan (untuk mencapai kesempurnaan jiwa). ${ }^{44}$ Ada juga yang mencoba mendefinisikan sebagai suatu ilmu yang membahas masalah pendekatan diri manusia kepada Tuhan melalui penyucian rohnya, ${ }^{45}$ dengan ilmu tersebut dapat diketahui hal ihwal kebaikan dan keburukan jiwa, cara membersihkannya dari sifat-sifat yang buruk dan mengisinya dengan sifat-sifat yang terpuji, cara melakukan suluk, melangkah menuju keridhaan Allah dan meninggalkan larangan-Nya menuju kepada perintah-Nya. ${ }^{46}$ Pandangan lain juga menyatakan bahwa tasawuf adalah ilmu yang menerangkan hal-hal tentang cara mensucibersihkan jiwa, tentang cara memperbaiki akhlaq dan tentang cara pembinaan kesejahteraan lahir dan batin untuk mencapai kebahagiaan yang abadi. $^{47}$

Aspek yang perlu digarisbawahi dalam melihat atau memunculkan definisi tersebut adalah bentuk pengalaman spiritual yang memungkinkan seseorang untuk mengalami puncak spiritualitasnya. Pada konteks ini, Asep Usman Ismail mengklaim bahwa ketika seseorang mengartikan tasawuf, maka ia tidak bisa lepas dari pengalaman spritualitas subjektifitasnya. ${ }^{48}$ Artinya, makna tasawuf sangat tergantung pada

\footnotetext{
${ }^{42}$ Ibnu Khaldun, Muqaddimah Ibn Khaldun, Peterj. Ahmadie Thoha (Jakarta: Pustaka Firdaus, 2003), 624.

${ }^{43}$ Tim Penyusun, Kamus Besar Bahasa Indonesia (Jakarta: Balai Pustaka, 2002), 1147

${ }^{44}$ Pius A. Partanto \& M. Dahlan A1 Barry, Kamus Ilmiah Populer (Surabaya: Arkola, 1994), 740.

${ }^{45}$ Budhy Munawar-Rachman (Editor), 42.

${ }^{46}$ Mahyuddin, 44.

${ }^{47}$ Mustafa Zahri, 46.

${ }^{48}$ Asep Usman Ismail, 305.
}

diri seorang manusia yang telah mengalami puncak spritualitas yang pernah ia alami sendiri. Pada fase ini sosok seorang sufi akan mengalami berbagai "peristiwa" yang membentuk konsepsi atas tasawuf sebagai suatu tatanan metodologi untuk menggapai kebenaran yang hakiki (Tuhan). Puncak pengalaman spiritual oleh seorang sufi merupakan fakta yang terus dicari dan hal ini sama seperti Nabi Muhammad Saw ketika mencapai derajat kewahyuan atau ketuhanan. Nabi Muhammad Saw memang secara khusus merupakan manusia pilihan dan tingkat pengalamannya jauh melampaui apa yang para pencari spiritual harapkan untuk mencapainya. Namun demikian, para sufi telah lama menganggap Nabi terakhir tersebut sebagai teladan pengabdian, kesederhanaan hidup, pencapaian mistis, dan otoritas spiritual. ${ }^{49}$

Dalam beberapa makna tasawuf yang telah muncul terdapat dua hal pokok yang menjadi inti dari tasawuf itu sendiri, yaitu: pertama, kesucian jiwa untuk menghadap Tuhan sebagai Zat Yang Maha Suci; dan kedua, upaya pendekatan diri secara individual kepada-Nya. ${ }^{50}$ Pada sisi faktual, makna atau definisi tasawuf tidak akan pernah lepas dari dua inti pokok tersebut dan juga diterjemahkan dalam bentuk aplikasi (perilaku) atau telah menjadi bagian dari perilaku sufistik. Oleh sebab itu, ada kalangan yang mensinyalir batasan tasawuf sebagai suatu nilai dan norma yang teraktualisasikan dalam bentuk perilaku. Ia membatasi tasawuf sebagai "budi-pekerti" dan secara ilustratif ia mendeskripsikan bahwa barangsiapa yang memberikan bekal budi-pekerti atasmu, berarti ia memberikan bekal atas dirimu dalam tasawuf. Maka hamba yang jiwanya menerima (perintah) untuk beramal, karena sesungguhnya mereka melakukan suluk dengan nur (cahaya) Islam. Dan ahli zuhud yang jiwanya menerima (perintah) untuk melakukan akhlaq (terpuji), karena mereka telah melakukan suluk

\footnotetext{
${ }^{49}$ John Renard, Historical Dictionary of Sufism (Toronto: The Scarecrow Press, Inc., 2005), 2.

${ }^{50}$ Asep Usman Ismail, 305.
} 
dengan nur (cahaya) imannya. ${ }^{51}$ Konsekuensinya ketika batasan tersebut menjadi suatu ketetapan, maka tasawuf merupakan bentuk jalan menuju pada kebenaran hakiki (Tuhan) dengan jalan mengosongkan berbagai bentuk sifat kefanaan ${ }^{52}$ yang pada gilirannya para sufi pada saat yang sama dikenal sebagai 'abid (para ahli ibadah) melalui syari' at, tarekat, hakekat, dan makrifat.

\section{Syari'ah dan Tasawuf: Integralistik- Monokhotomik}

Non-Muslim sering mengalami kesalahan dalam memahami tasawuf yang dinilai sebagai sekte dalam Islam. Padahal kalau sedikit lebih terbuka, tasawuf sebenarnya lebih tepat disebut sebagai aspek atau dimensi mistik dalam Islam. Sosok seorang sufi (tarekat) atau praktik tasawuf dapat ditemukan dalam Sunni, Syiah, dan kelompok Islam lainnya sebagai satu entitas dalam mencari kebenaran hakiki. Ibnu Khaldun (1332-1406 M.), sejarahwan Arab abad ke-14, menggambarkan tasawuf sebagai pelaksanaan yang bersifat ajeg dalam beribadah, kesetiaan yang penuh kepada Allah, enggan pada kesemarakan kosong di dunia, pantang dari kesenangan harta, dan kedudukan seperti yang dicita-citakan banyak orang, dan menjauhkan diri dari dunia serta pergi berkhalwat untuk beribadah. ${ }^{53}$ Artinya, praktik sufi yang lebih memprioritaskan dimensi esoterik tidak serta merta meninggalkan dimensi eksoterik, sebab praktik ibadah syari' ah yang termanifestasi dalam bentuk Fiqh (hukum Islam) menjadi jalan untuk untuk menemukan kebenaran dari kasih Ilahi dan pengetahuan melalui pengalaman pribadi langsung dari Tuhan.

\footnotetext{
${ }^{51}$ Mahyuddin, 45.

${ }^{52}$ Fanaa secara filosofis adalah meniadakan diri supaya "ada". Menurut al-Qusyairi untuk mencapai fanaa ada tiga tingkatan, yaitu: (1) fana' dari dirinya, fana' dari sifatnya karena baqa'nya sifat-sifat al-Haqq; (2) fana'nya dari sifat-sifat al-Haqq, karena penyaksiaannya terhadap al-Haqq itu sendiri; dan(3) fana'nya dari melihat penyaksian fana', melalui peleburan dirinya dalam wujud al-Haqq. Lihat dalam Syamsun Ni'am, Cinta Ilahi PerspektifRabi'ah al-Adawiyah dan Jalaluddin Rumi (Surabaya: Risalah Gusti, 2001), 94-95.

${ }^{53}$ Ibnu Khaldun, 623.
}

Salah satu tokoh sufi, Abu al-Ali al-Daqqaq (w. 406 H./1015 M.) dan juga Hujjatul Islam yaitu al-Ghazali memberi penjelasan yang cukup menarik tentang konsep integralistik ini dengan nash normatif QS. al-Fatihah ayat 4 dan 5. Al-Ghazali memandang seluruh ayat dalam al-Fatihah merupakan ayat-ayat jawahir (mutiara) yang mengandung nilai-nilai uluhiyah yang tinggi. Pada nash normatif bahwa "Iyya ka na'budu (Hanya kepada-Mu kami menyembah)" (QS. al-Fatihah: 4) merupakan bentuk manifestasi dari syari'ah sebagai dimensi eksoteris; atau merupakan bentuk ubudiyah hamba dalam situasi fana'. Sedangkan untuk mengisi dimensi esoteris sebagai perwujudan proses pembersihan jiwa dari sifat-sifat kemanusiaan (al-nasut) disandarkan pada “Iyya ka nasta'iin (Hanya kepada-Mu kami memohon)" (QS al-Fatihah: 5); ayat ini merupakan bentuk manifestasi dari pengakuan (penetapan) dimensi hakikat (esoteris). Pada arus dua dimensi (QS. al-Fatihah ayat 4 dan 5) ini, dimensi eksoteris (syari'ah) adalah dimensi esoteris (hakikat) dari sisi mana kewajiban diperintahkan, begitu pula sebaliknya dimensi esoteris (hakikat) pada polanya merupakan dimensi eksoteris (syari'ah) dari sisi mana kewajiban (bentuk ritual-ritual seperti ibadah shalat) diperintahkan bagi para sufi. ${ }^{54}$ Dengan demikian, dua ayat ini memberikan ruang untuk seorang hamba masuk dan tenggelam dalam kesatuan penyaksian, yang jika meminjam istilah dari Yazid al-Busthami (804-875 M.) disebut sebagai al-wahdatul al-syuhud.

Pada tataran ini, para sufi yang terlibat dalam berbagai praktik ritual (dimensi eksoteris/ syari'ah) dimaksudkan membantu mereka untuk mewujudkan penyatuan dengan Tuhan, seperti bentuk-bentuk yang berbeda dari doa ritual (zikir yang secara harfiah berarti mengingat),

\footnotetext{
${ }^{54}$ Lihat detailnya Shashi Shekhar Sharma, Caliphs and Sultans: Religious Ideology and Political Praxis (New Delhi: Rupa \& Co., 2004), 223; Imam al-Ghazali, Jawahirul Quran: Permata Ayat-Ayat Suci, Peterj. Mohammad Luqman Hakiem (Surabaya: Risalah Gusti, 1996).
} 
termasuk pembacaan nama-nama Allah. Para sufi mengembangkan praktik-praktik keagamaan yang fokus utamanya pada pengontrolan diri secara ketat yang memungkinkan wawasan psikologis dan mistis serta hilangnya diri, dengan tujuan akhir dari kesatuan mistik dengan Tuhan. Disebabkan tujuan tasawuf yang demikian, maka ada sebagian kalangan yang mengklaim bahwa tasawuf lepas dari alur tujuan syari'ah sebagai bentuk tujuan melaksanakan perintah dan menjauhi segala bentuk larangan Tuhan. Padahal melalui dimensi eksoteris (syari'ah), sosok seorang sufi mampu untuk membersihkan sifat-sifat kemanusiaan (al-nasut) yang akhirnya diisi dengan sifat-sifat ketuhanan (al-lasut). ${ }^{55}$

Dari dasar itu pula muncul juga suatu kritik bahwa tasawuf hanya bersifat god oriented an sich yang akhirnya meninggalkan - baca acuh tak acuh - terhadap persoalan dunia. Namun, kritik tersebut sangat tidak mendasar jika dilihat dari sisi historisnya banyak kalangan sufi yang aktivitasnya berorientasi pada hal-hal yang bersifat profan, seperti yang terlihat pada Sufisme Persian pada periode Seljuk ${ }^{56}$ yang aktivitas sufi banyak yang dilakukan ke ranah politik, dan sebagian kecil bidang istishab; ar-Raniry sebagai mufti dan Hamzah Fansuri sebagai pedagang. Bahkan ada juga sufi yang tidak menjauhi kehidupan duniawi (profan). Mereka memberikan sumbangan yang besar dalam pengembangan berbagai bidang kehidupan. Dalam pendidikan, para sufi seperti Khwajah Nizam al-Mulk, wazir Dinasti Saljuk, berpartisipasi langsung membangun universitas-

\footnotetext{
${ }^{55}$ Pandangan bahwa Tuhan dan manusia mempunyai sifat dasar yang sama diambil dari sebuah hadis yang berarti "sesungguhnya Allah menciptakan Adam sesuai dengan bentuk-Nya (HR. Bukhari, dan Ahmad bin Hanbal). Hadis ini mengandung arti bahwa dalam diri Adam AS terdapat "bentuk" Tuhan yang disebut dengan al-lasut. Sebaliknya, di dalam diri Tuhan terdapat "bentuk" manusia yang disebut al-nasut. Berdasarkan adanya paham kesamaan sifat antara Tuhan dan manusia, maka persatuan atara Tuhan dan manusia itu mungkin terjadi. Dewan Redaksi Ensiklopedi Islam, Ensiklopedi Islam (Jakarta: PT. Ichtiar Baru van Hoeve, 2003), 75.

${ }^{56}$ Lihat detailnya dalam Hamid Dabasyi, Seri Pengantar Tasawuf: Sufisme Persia Dalam Periode Seljuk, Peterj. Gafna Raizha Wahyudi (Yogyakarta: Pustaka Sufi, 2003).
}

universitas atau madrasah-madrasah. ${ }^{57}$

Berdasarkan pada praktik ibadah para sufi tersebut sangat jelas bahwa praktik tasawuf didasarkan pada kemurnian kehidupan, ketaatan yang ketat terhadap hukum Islam (syari'ah) dan meniru pola kehidupan para nabi dalam Islam. Melalui penyangkalan diri, introspeksi diri (muhasabah), hati-hati dalam bertindak dan perjuangan mental, para sufi berharap dapat memurnikan diri dari segala keegoisan diri, sehingga ia mampu mencapai derajat keikhlasan yang tinggi, dan kemurnian niat yang mutlak dalam tindakan. Hal yang demikian sangat sesuai dengan esensi ajaran Mansur al-Hallaj yang menekankan pada perbaikan moral dan pada pengalaman persatuan dengan yang dicintai, yaitu Tuhan. ${ }^{58}$ Dengan demikian, seorang sufi sebenarnya memberikan motivasi konstruktif dalam setiap ajaran tentang kehidupannya dalam aspek hubungan dengan sesama (ibadah ghairu mahdah) maupun dengan Tuhan (ibadah mahdah). Artinya, pola kehidupan yang demikian akan mendorong manusia untuk terus hidup dinamis.

Dalam aspek hubungan dengan sesama manusia (ibadah ghairu mahdah) dan hubungan dengan Tuhan (ibadah mahdah), antara syari'ah dan tasawuf tidak akan pernah bertolak belakang (disintegratif-dikhotomik), tapi bisa berdialektika dalam bingkai integratif-monokhotomik, yaitu saling mengisi secara kontributif dalam satu tujuan, yaitu Tuhan. Secara sosial - hal ini bisa dilihat sebagai gejala sosial-keagamaan - kehidupan tasawuf merupakan suatu revolusi ruhani, sehingga seseorang yang benar-benar berjalan pada kehidupan tasawuf yang benarbenar lurus, maka profesi dan karirnya tidak

\footnotetext{
${ }^{57}$ Kautsar Azhari Noer, "Menyemarakkan Dialoq Agama: Perspektif Kaum Sufi", dalam Edy A. Effendy (Editor), Dekonstruksi Islam Mazhab Ciputat (Bandung: Zaman Wacana Mulia, 1999), 48.

${ }^{58}$ Kautsar Azhari Noer, "Tasawuf Filosofis", dalam dalam Taufik Abdullah, dkk., Ensiklopedi Tematis Dunia Islam: Pemikiran dan Peradaban, Jilid 4 (Jakarta: PT. Ichtiar Baru Van Hoeve, 2002), 159
} 
akan terhambat. Umar Ibn' Abdul Aziz (61101 H./682-722 M.) adalah seorang sufi yang sukses sebagai pemimpin negara, Imam Junayd al-Baghdadi (210-297 H./ 832-919 M.) sukses sebagai seorang pengusaha botol, Mansur alHallaj (244-309 H./858-922 M.) sukses sebagai pengusaha tenun. ${ }^{59}$ Di sisi lain, seperti yang disinggung pada awal tulisan ini, bahwa tasawuf merupakan salah satu gerakan keagamaan yang muncul dan berkembang diakibatkan oleh kondisi sosio-politik pada masa rezim pemerintahan kaum Umawi di Damaskus; yang secara general mereka diklaim kurang religius dalam praktik kehidupannya. ${ }^{60} \mathrm{Hal}$ ini berarti tasawuf tidak hanya berorientasi pada sisi transendental, akan tetapi juga tidak mengabaikan sisi yang bersifat humanistik seperti sosial, politik, ekonomi, budaya, pendidikan sampai dakwah.

Begitu pula pada aspek hubungan dengan Tuhan, antara syari'ah dan tasawuf tetap menjadi dua entitas yang saling mengisi (dialektika) dalam satu kesatuan menuju Tuhan. Syari'ah merupakan bentuk yang bernuansa hukum (eksoteris, seperti pemenuhan dalam syarat dan rukun dalam setiap ibadah, sedangkan tasawuf merupakan bentuk tinjauan esoteris yang bisa diidentikkan dengan konsep ihsan. Dengan dua dimensi ini akan semakin memantapkan kualitas dari keimanan sosok muslim yang nantinya menemukan kebenaran yang hakiki (Tuhan) melalui dua dimensi, yaitu rasional (eksoteris) dan rasa (esoteris). Oleh sebab itu, para praktisi hukum agar tidak menggunakan metode rasional melibihi kapasitas atau jangkauannya. Di lain pihak, para fuqaha juga tidak berhak mengklaim bahwa apa yang mereka temukan melalui metode rasional ini adalah makna yang sesungguhnya dari hukum Tuhan dan merupakan kebenaran

\footnotetext{
${ }^{59}$ Said Agiel Siradj, Ahlussunnah Wal Jama'ah dalam Lintas Sejarah (Jakarta: LKPSM, 2001), 97.

${ }^{60}$ Nurcholis Madjid, "Disiplin Keilmuan Islam Tradisional: Tasawuf (Letak dan Peran Mistisisme dalam Penghayatan Keagaman Islam", dalam Budhy Munawar-Rachman (Editor), Islam, Doktrin dan Peradaban (Jakarta: Paramadina, 1994), 24.
}

hakiki. Karena jika demikian, mereka telah salah mengaplikasikan atau mungkin telah menyalahgunakan keahlian dan metodologi yang mereka miliki. Apabila menginginkan hal itu, mereka harus menggunakan, menerima, atau menyerahkan pada metode yang sesuai untuk itu, yaitu metode penyingkapan kebenaran (kasyf) ${ }^{61}$

\section{Kesimpulan}

Hukum Islam (syari'ah) yang sering dihadapkan secara vis a vis dengan tasawuf ternyata merupakan dua entitas yang saling mengisi secara kontributif untuk memantapkan kualitas dari keimanan seorang muslim. Artinya, pada aspek hubungan dengan sesama manusia (ibadah ghairu mahdah) dan hubungan dengan Tuhan (ibadah mahdah), antara syari'ah dan tasawuf tidak bertolak belakang (disintegratifdikhotomik), tapi bisa berdialektika dalam bingkai integratif-monokhotomik, yaitu saling mengisi secara kontributif dalam satu tujuan, yaitu Tuhan. Walaupun telah berabad-abad lamanya antara varian Syari'ah dengan Tasawuf saling mengkritik tentang keabsahan masing-masing dimensi, di mana syariah lebih memusatkan pada dimensi eksoteris dan tasawuf pada dimensi esoteris; akhirnya percikan kritik ini menciptakan rentetan alur sejarah peradaban Islam itu sendiri. Sufisme membingkai integralisme dalam konsep syari'at, tarekat, hakekat, dan makrifah.

\section{Daftar Kepustakaan}

A. Qodri Azizy. Membangun Fondasi Ekonomi Umat: Meneropong Prospek Berkembangnya Ekonomi Islam. Yogyakarta: Pustaka Pelajar, 2004.

Aan Rukmana, dkk. Mengenal Islam Jalan Tengah: Buku Daras Pendidikan Agama Islam untuk Perguruan Tinggi. Jakarta: Dian Rakyat, 2012.

\footnotetext{
${ }^{61}$ Nurasiah Faqihsutan Hrp 49.
} 
Abuddin Nata. Metodologi Studi Islam. Jakarta: Rajawali Press, 2011.

Amstrong, Karen. A History of God: The 4,000Year Quest of Judaism, Christianity, and Islam. Peterj. Zainul Am. Bandung: Mizan, 2002.

Asmaran AS. Pengantar Studi Tasawuf Jakarta: Rajawali Press, 1996.

Budhy Munawar-Rachman (Editor). Islam, Doktrin dan Peradaban. Jakarta: Paramadina, 1994.

Kontekstualisasi Doktrin Islam dalam Sejarah. Jakarta: Paramadina, 1994.

Campo, Juan E. Encyclopedia of Islam. New York: Facts On Fire, Inc., 2009.

Chittick, William C. Sufism: A Beginner's Guide. Oxford: A Oneworld Book, 2008.

Dabasyi, Hamid. Seri Pengantar Tasawuf: Sufisme Persia Dalam Periode Seljuk. Peterj. Gafna Raizha Wahyudi. Yogyakarta: Pustaka Sufi, 2003.

Dahlen, Ashk P. Islamic Law, Epistemology and Modernity: Legal Philosophy in Contemporary Iran. New York: Routledge, 2003.

Dewan Redaksi Ensiklopedi Islam. Ensiklopedi Islam. Jakarta: PT. Ichtiar Baru van Hoeve, 2003.

Edy A. Effendy (Editor). Dekonstruksi Islam Mazhab Ciputat. Bandung: Zaman Wacana Mulia, 1999.

Ellwood, Robert S. \& Alles, Gregory D. The Encyclopedia of World Religions: Revised Edition. New York: Facts On File, Inc., 2007.

Fealy, Greg \& Hooker, Virginia (Editor). Voices of Islam In Southeast Asia: A Contemporary Source Book. Singapore: ISEAS, 2006.

Geoffroy, Eric. Introduction to Sufism: The Inner
Path of Islam. Indiana: World Wisdom, Inc., 2010.

Hallaq, Wael B. An Introduction to Islamic Law. Cambridge: Cambridge University Press, 2009.

Hassan, Ahmad. The Principles of Islamic Jurisprudence: The Command of The Syari' ah and Juridical Norm. New Delhi: Adam Publisher \& Distributor, 1994.

Ibnu Khaldun. Muqaddimah Ibn Khaldun. Peterj. Ahmadie Thoha, Jakarta: Pustaka Firdaus, 2003.

Imam al-Ghazali. Jawahirul Quran: Permata Ayat-ayat Suci. Peterj. Mohammad Luqman Hakiem. Surabaya: Risalah Gusti, 1996.

Kamali, Mohammad Hashim. Shari'ah Law: An Introduction. Oxford: A Oneworld Book, 2008.

Kheirabadi, Masoud. Religions of the World: Islam. Philadelphia: Chelsea House Publishers, 2004.

M. Amin Abdullah. Studi Agama: Normativitas atau Historisitas? Yogyakarta: Pustaka Pelajar, 2002.

Mahyuddin. Kuliah Akhlaq Tasawuf. Jakarta: Kalam Mulia, 2003.

Muhaimin, dkk. Studi Islam: dalam Ragam Dimensi \& Pendekatan. Jakarta: Prenada Media, 2012.

Muniron, dkk. Studi Islam di Perguruan Tinggi. Jember: STAIN Jember Press, 2010.

Mustafa Zahri Kunci Memahami Ilmu Tasawuf. Surabaya: Bina Ilmu, 1995.

Nurasiah Faqihsutan Hrp. Meraih Hakikat Melalui Syariat: Telaah Pemikiran Syekh al-Akbar Ibn 'Arabi. Bandung: Mizan, 2005.

Nurcholish Madjid. Islam Agama Peradaban: 
Membangun Makna dan Relevansi Doktrin

Islam dalam Sejarah. Jakarta: Paramadina, 2000.

Islam Doktrin dan Peradaban: Sebuah Telaah Kritis Tentang Masalah Keimanan, Kemanusiaan, dan Kemodernan. Jakarta: Paramadina, 2000.

Pius A. Partanto \& M. Dahlan Al Barry. Kamus Ilmiah Populer. Surabaya: Arkola, 1994.

Rahman, Fazlur. Islam. Peterj. Ahsin Mohammad. Bandung: Pustaka, 1984.

Renard, John. Historical Dictionary of Sufism. Toronto: The Scarecrow Press, Inc., 2005.

. The A to $Z$ of Sufism. Toronto: The Scarecrow Press, Inc., 2009.

Said Agiel Siradj. Ahlussunnah Wal Jama'ah dalam Lintas Sejarah. Jakarta: LKPSM, 2001.

Schwartz, Stephen Sulaiman. Two Faces of Islam: The House of Sa'ud from Tradition to Terror. Peterj. Hodri Ariev. Jakarta:
Blantika, 2007.

Suhrawardi, Syihabuddin 'Umar. 'Awarif alMa'arif: Puncak Pengetahuan Ahli Makrifat. Peterj. Ilma Nugrahani Ismail. Bandung: Pustaka Hidayah, 2007.

Sulaiman Rasjid. Fiqh Islam: Hukum Fiqh Lengkap. Bandung: Sinar Baru Algensindo, 2002.

Syamsun Ni'am. Cinta Ilahi Perspektif Rabi'ah al-Adawiyah dan Jalaluddin Rumi. Surabaya: Risalah Gusti, 2001.

Taufik Abdullah, dkk. Ensiklopedi Tematis Dunia Islam: Ajaran. Jilid 3. Jakarta: PT. Ichtiar Baru Van Hoeve, 2002.

------. Ensiklopedi Tematis Dunia Islam: Pemikiran dan Peradaban. Jilid 4. Jakarta: PT. Ichtiar Baru Van Hoeve, 2002.

Tim Penyusun. Kamus Besar Bahasa Indonesia. Jakarta: Balai Pustaka, 2002. 